\title{
Remazol black dye (reactive black 5) decolorization by horseradish peroxidase enzyme
}

\begin{abstract}
The Enzymatic processes have been regarded as a promising alternative for the treatment of textile effluents that have high dyes content. The aim of this study was to evaluate the influence of different parameters on the decolorizing process of aqueous solutions of Remazol black dye (Reactive Black 5) by horseradish peroxidase enzyme. The studied parameters were enzyme concentration, hydrogen peroxide concentration, $\mathrm{pH}$, and temperature by using a $4^{2}$ experimental design with triplicate at the central point. From the best condition, $\mathrm{pH} 4$, higher enzyme concentration, and $3 \times 10^{-4} \mathrm{mM}$ of hydrogen peroxide concentration, the enzymatic treatment showed $77.7 \%$ of remazol black dye (Reactive Black 5) decolorization, showing this treatment as a promising methodology to dye removal.
\end{abstract}

Keywords: horseradish peroxidase, dye removal, textile effluent
Volume 4 Issue 2 - 2018

\author{
Janaína Duarte Baumer, Alexsandra Valério, \\ Selene MA Guelli Ulson de Souza, Gilmar \\ $S$ Erzinger, Agenor Furigo, Antônio Augusto \\ Ulson de Souza \\ Department of Chemical and Food Engineering, Federal \\ University of Santa Catarina, Brazil
}

\begin{abstract}
Correspondence: Antônio Augusto Ulson de Souza, Department of Chemical and Food Engineering, Federal University of Santa Catarina - UFSC, Florianópolis, SC- Brazil , Zip code: 88040-900, Tel +55 (48) 372I-25I3, 372 I-6444, Email antonio.augusto.souza@ufsc.br
\end{abstract}

Received: February 16, 2018 | Published: March 13, 2018

\section{Introduction}

The textile industry is one of the most pollutants releasing industries due to the colored aqueous effluents, which extensively use synthetic chemicals as dyes. ${ }^{1,2}$ The effluents from textile industry have high Chemical Oxygen Demand (COD), Biological Oxidation Demand (BOD), presence of metal ions, and high dissolved solids content (TDS) ${ }^{1-3}$ The color removal, especially from textile effluents, has been a major challenge over the last decades, and currently, there is no related a single one-step and economically attractive treatment that can effectively minimize the effluents contamination. Thus, the study and development of alternative and high-efficiency processes for the treatment of industrial effluents are extreme importance, ${ }^{4}$ and have attracted the attention of researchers, environmentalists, and governments.

In general, the traditional treatment of textile effluent is based on the physical-chemical precipitation, coagulation followed by biological treatment via activated sludge process. Although these systems have high efficiency, with good results in terms of carbonaceous reduction allowing $80 \%$ of initial load removal, they show high sludge production as a drawback, requirement of large areas for process implantation and industrial sanitary landfills. ${ }^{2,5}$ Therefore, the problem related to the sludge accumulation becomes critical, once the dye content adsorbed is high and becomes the reuse unworkable. ${ }^{1,3,6}$

In this context, the use of biological processes based on enzyme as a catalyst has emerged as an alternative with wide potential. The use of enzymes in the treatment of effluents, compared to the conventional processes, above mentioned, shows as main advantages the degradation of toxic or recalcitrant compounds and the operability at high contaminants concentration, and mild $\mathrm{pH}$ and temperature condition. ${ }^{2-4,7}$ Moreover, other advantages of the enzymatic process are the absence of biomass production, low organic load, and absence of acclimatization period.
Thereby, the demand for efficient and green oxidation technologies has increased interest in the use of enzymes to replace conventional non-biological methods. In front of this scenario, the aim of this work was to study the influence of enzyme concentration, hydrogen peroxide concentration, $\mathrm{pH}$, and temperature in the enzymatic remazol black dye (Reactive Black 5) decolorization from aqueous solutions by using horseradish peroxidase enzyme (HPE).

\section{Material and methods}

\section{Materials}

In this work, remazol black (Reactive Black 5) used as dye, was kindle donated by Karsten company. A free horseradish peroxidase enzyme (HRP) was kindly donated by Toyobo Brazil.

\section{Experimental procedure}

The decolorization experiments were carried out in batch with $100 \mathrm{~mL}$ as reaction volume at $50 \mathrm{mg} / \mathrm{L}$ of black remazol dye for all experiments. The evaluated reaction conditions were horseradish peroxidase concentration $[\mathrm{E}]$, hydrogen peroxide concentration $\left[\mathrm{H}_{2} \mathrm{O}_{2}\right], \mathrm{pH}$, and temperature $(\mathrm{T})$ according to the $2^{4}$ factorial designs with triplicate at the central point (Table 1). The $\mathrm{pH}$ was kept using the citrate-phosphate buffer ( $\mathrm{pH} 4$ and 5) and phosphate buffer ( $\mathrm{pH}$ 6.0 ) at $0.05 \mathrm{~mol} / \mathrm{L}$. The decolorizing of the remazol black dye (\%) was evaluated after $60 \mathrm{~min}$, and the color reduction was calculated using the equation reported by Dafale et al. ${ }^{7}$ Statistic software ${ }^{\circledR} 10$ (Statsoft Inc) was used to assist the design and statistical analysis. The model fit was evaluated by the coefficient of determination $\left(\mathrm{R}^{2}\right)$ and analysis of variance (ANOVA).

The enzymatic activity was determined by spectrophotometry (UVVis, Shimadzu) using ABTS [2,2'-azino-bis (3-ethylbenzthiazoline-6sulfonic acid)] as substrate. The ABTS is oxidized by the peroxidase enzyme in the presence of hydrogen peroxide producing the cation ABTS + . The rate of cation formation is proportional to the enzyme 
activity. The oxidation reaction was conducted using $2.19 \mathrm{~mL}$ of phosphate buffer ( $\left.\mathrm{pH} 6,0.05 \mathrm{molL}^{-1}\right), 0.300 \mathrm{~mL}$ of enzyme extract, $0.255 \mathrm{~mL}$ of $20 \mathrm{mM}$ ABTS and $0.255 \mathrm{~mL}$ of $10 \mathrm{mM}$ hydrogen peroxide $\left(\mathrm{H}_{2} \mathrm{O}_{2}\right)$. The substrate oxidation was monitored for $5 \mathrm{~min}$ in a spectrophotometer at $420 \mathrm{~nm}$. A unit of enzyme activity (U) was defined as the amount of enzyme that converts $1 \mu \mathrm{mol}$ of ABTS to the radical cation per minute.

\section{Results and discussion}

The Table 1 shows the experimental assays carried out according to the $2^{4}$ factorial designs, with response in terms of dye removal. As observed, the maximal decolorizing the dye solution was obtained in the assay 12 , leading to a $77.7 \%$ of remazol black dye solution decolorization. Ashrafi et al., ${ }^{8}$ reported high decolorization percentage by using Acid Red 18 (97\%) followed by Direct Red 81 (68.3\%),
Reactive Yellow 15 (60.2\%), and Disperse Blue 56 (58\%) after 15 min using the purified laccase from Paraconiothyrium variabile as enzyme at $0.1 \mathrm{U} \mathrm{mL}^{-1}$.

From the experimental design results, it was possible to obtain the Pareto chart (Figure 1), that shows the effects of the experimental variables on the remazol black dye decolorization under the studied conditions. Figure 1 shows the Pareto chart with the independent studied variables in terms of remazol black dye decolorization by horseradish peroxidase enzyme. It is clear from the figure that the variables with the significant effect $(\mathrm{p}<0.05)$ were $\mathrm{pH}$, with a negative effect, and enzyme concentration, with a positive effect. The best conditions of decolorization were at $\mathrm{pH} 4$ (level -1) and enzyme concentration at level $+1(39.97 \mathrm{U} / \mathrm{mL})$. On the other hand, the temperature not showed significant effect $(\mathrm{p}<0.05)$ on the decolorization remazol black dye.

Table I Matrix of experimental design (real and coded values) with the response in terms of dye removal

\begin{tabular}{|c|c|c|c|c|c|c|c|c|c|}
\hline Exp. & {$[\mathbf{E}](\mathbf{U} / \mathbf{m L})$} & Level & {$\left[\mathrm{H}_{2} \mathbf{O}_{2}\right](\mathbf{m M})$} & Level & pH & Level & $\mathbf{T}\left({ }^{\circ} \mathbf{C}\right)$ & Level & Decolorization (\%) \\
\hline 1 & 2.1 & $(-1)$ & $3 \times 10^{-5}$ & $(-1)$ & 4 & $(-1)$ & 20 & $(-1)$ & 10.2 \\
\hline 2 & 39.97 & (1) & $3 \times 10^{-5}$ & $(-1)$ & 4 & $(-1)$ & 20 & $(-1)$ & 51.5 \\
\hline 3 & 2.1 & $(-1)$ & $3 \times 10^{-4}$ & (1) & 4 & $(-1)$ & 20 & $(-1)$ & 11.43 \\
\hline 4 & 39.97 & (1) & $3 \times 10^{-4}$ & (1) & 4 & $(-1)$ & 20 & $(-1)$ & 75.15 \\
\hline 5 & 2.1 & $(-1)$ & $3 \times 10^{-5}$ & $(-1)$ & 6 & (1) & 20 & $(-1)$ & 1.22 \\
\hline 6 & 39.97 & (1) & $3 \times 10^{-5}$ & $(-1)$ & 6 & (1) & 20 & $(-1)$ & 7.69 \\
\hline 7 & 2.1 & $(-1)$ & $3 \times 10^{-4}$ & (1) & 6 & (1) & 20 & $(-1)$ & 1.16 \\
\hline 8 & 39.97 & (1) & $3 \times 10^{-4}$ & (1) & 6 & (1) & 20 & $(-1)$ & 6.33 \\
\hline 9 & 2.1 & $(-1)$ & $3 \times 10^{-5}$ & $(-1)$ & 4 & $(-1)$ & 40 & $(-1)$ & 13.82 \\
\hline 10 & 39.97 & (1) & $3 \times 10^{-5}$ & $(-1)$ & 4 & $(-1)$ & 40 & (1) & 72 \\
\hline 11 & 2.1 & $(-1)$ & $3 \times 10^{-4}$ & (1) & 4 & $(-1)$ & 40 & (1) & 13.27 \\
\hline 12 & 39.97 & (1) & $3 \times 10^{-4}$ & (1) & 4 & $(-1)$ & 40 & (1) & 77.7 \\
\hline 13 & 2.1 & $(-1)$ & $3 \times 10^{-5}$ & $(-1)$ & 6 & (1) & 40 & (1) & 6.36 \\
\hline 14 & 39.97 & (1) & $3 \times 10^{-5}$ & $(-1)$ & 6 & (1) & 40 & (1) & 16.73 \\
\hline 15 & 2.1 & $(-1)$ & $3 \times 10^{-4}$ & (1) & 6 & (1) & 40 & (1) & 2.3 \\
\hline 16 & 39.97 & (1) & $3 \times 10^{-4}$ & (1) & 6 & (1) & 40 & (1) & 7.21 \\
\hline 17 & 21.04 & (0) & $2 \times 10^{-4}$ & $(0)$ & 5 & (0) & 30 & (0) & 19.07 \\
\hline 18 & 21.04 & (0) & $2 \times 10^{-4}$ & (0) & 5 & (0) & 30 & (0) & 18.26 \\
\hline 19 & 21.04 & $(0)$ & $2 \times 10^{-4}$ & $(0)$ & 5 & $(0)$ & 30 & $(0)$ & 18.54 \\
\hline
\end{tabular}

Equation 1 presents the first-order coded model, which describes the decolorization of the remazol black dye as a function of the independent variables (factors) analyzed $(\mathrm{pH}$, enzyme concentration, and temperature) within the studied range. The factors that were not significant $(\mathrm{p}<0.05)$ were added to the lack of fit for the variance analysis. The coded model can be used for the evaluation of parameters in the evaluated range since it was validated by variance analysis. The correlation coefficient (0.98) and the F-test for regression demonstrated the good representation of experimental information by the model. 


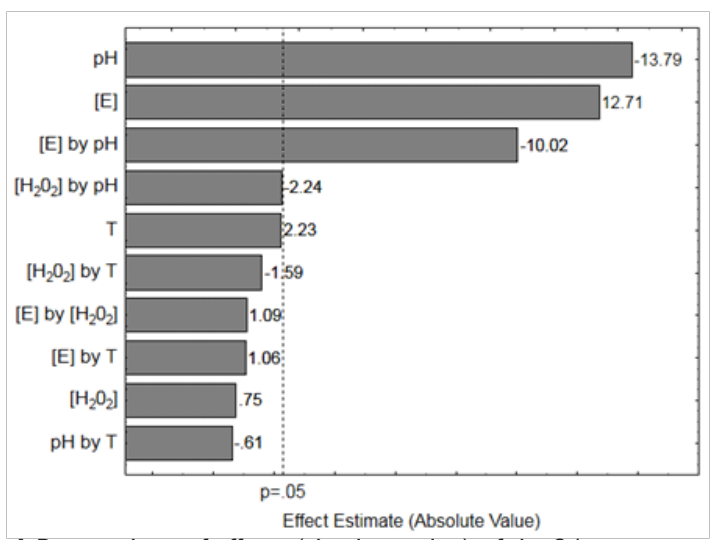

Figure I Pareto chart of effects (absolute value) of the 24 experimental designs for the decolorization of the remazol black dye
Decolorization $(\%)=22.54+31.86[\mathrm{E}]+1.87\left[\mathrm{H}_{2} \mathrm{O}_{2}\right]-34.50 \mathrm{pH}$ $+5.59 \mathrm{~T}+2.74[\mathrm{E}] \cdot\left[\mathrm{H}_{2} \mathrm{O}_{2}\right]-25.08[\mathrm{E}] \cdot \mathrm{pH}+2.65[\mathrm{E}] \cdot \mathrm{T}-5.62\left[\mathrm{H}_{2} \mathrm{O}_{2}\right]$. $\mathrm{pH}-3.98\left[\mathrm{H}_{2} \mathrm{O}_{2}\right] . \mathrm{T}-1.53 \mathrm{pH} . \mathrm{T}$ (1)

Where

[E]: enzyme concentration,

$\left[\mathrm{H}_{2} \mathrm{O}_{2}\right]$ : hydrogen peroxide,

T: temperature,

$\mathrm{pH}$ : hydrogen potential value.

The correlation coefficient obtained (0.98) and the F calculated (28.5 times higher than the listed value) (Table 2) allowed the validation of the empiric mathematic model (Eq. 1) at $\mathrm{p}<0.05$.

Table 2 Analysis of variance (ANOVA) for the decolorization of the remazol black dye $\left(R^{2}=0.98\right)$

\begin{tabular}{llllll}
\hline & Sun of square & Degrees of freedon & Mean square & $\mathbf{F}_{\text {calc }}$ & $\mathbf{F}_{\text {tab }}$ \\
\hline Regression & 11330.93 & 3 & 3776.97 & - & - \\
Residue & 602.35 & 15 & 40.15 & 94.05 & 3.29 \\
Lack of fit & 198.84 & 6 & 33.14 & - & - \\
Pure error & 6.52 & 2 & 3.26 & 10.16 & 19.33 \\
Total & 11933.27 & 18 & - & - & -
\end{tabular}

\section{Conclusion}

The horseradish peroxidase enzyme showed to be an efficient catalyst for the decolorization of the remazol black dye from aqueous solutions. The $\mathrm{pH}$ was the parameter that showed the highest influence on the dye removal reactions, followed by the enzyme concentration, with the best conditions being reached at $\mathrm{pH} 4$ and high enzyme concentration $(39.97 \mathrm{U} / \mathrm{mL})$. On the other hand, temperature not showed a significant effect on the remazol black dye decolorization, an important response, once that the temperature can be a limiting factor in many industrial processes.

\section{Acknowledgements}

CAPES for the financial support, Toyobo Brazil for the enzyme donation and the Karsten Company for the remazol black dye donation.

\section{Conflict of interest}

Authors declare there is no conflict of interest in publishing the article.

\section{References}

1. Li T, Guthrie JT. Colour removal from aqueous solutions of metalcomplex azo dyes using bacterial cells of Shewanella strain J18 143 Bioresour Technol. 2010;101(12):4291-5.
2. Singh RL, Singh PK, Singh RP. Enzymatic decolorization and degradation of azo dyes - A review. Int Biodeterior Biodegradation. $2015 ; 104: 21-31$

3. Husain Q. Potential Applications of the Oxidoreductive Enzymes in the Decolorization and Detoxification of Textile and Other Synthetic Dyes from Polluted Water: A Review. Crit Rev Biotechnol. 2006;26(4):20121.

4. Jamal F, Qidwai T, Pandey PK, et al. Azo and anthraquinone dye decolorization in relation to its molecular structure using soluble Trichosanthes dioica peroxidase supplemented with redox mediator. Catal Commun. 2011;12(13):1218-23.

5. Shivangi R, Richa S, Subhash C. Microbial degradation of synthetic textile dyes: A cost effective and eco-friendly approach. African $J$ Microbiol Res. 2013;7(24):2983-9.

6. Bamufleh HS. Single and binary sulfur removal components from model diesel fuel using granular activated carbon from dates' stones activated by $\mathrm{ZnCl}_{2}$. Appl Catal A Gen. 2009;365(2):153-8.

7. Dafale N, Wate S, Meshram S, et al. Kinetic study approach of remazol black-B use for the development of two-stage anoxic-oxic reactor for decolorization/biodegradation of azo dyes by activated bacterial consortium. J Hazard Mater. 2008;159(2-3):319-28.

8. Ashrafi SD, Rezaei S, Forootanfar H, et al. The enzymatic decolorization and detoxification of synthetic dyes by the laccase from a soil-isolated ascomycete, Paraconiothyrium variabile. Int Biodeterior Biodegradation. 2013;85:173-81. 